\title{
Identification of the Second Mutation of BADH2 Gene Derived from Rice Mutant Lines Induced by Gamma Rays
}

\author{
I. Ishak* \\ Center for Isotopes and Radiation Application, National Nuclear Energy Agency \\ Jl. Lebak Bulus Raya No. 49, Jakarta 12440, Indonesia
}

\section{ARTICLE INFO}

Article history:

Received 04 October 2014

Received in revised form 22 September 2015

Accepted 29 November 2015

Keywords:

Mutation;

Gamma irradiation;

Aromatic rice,

$\mathrm{BADH} 2$ gene analysis

\begin{abstract}
A B S T R A C T
The BADH2 gene acts as suppressor of 2-acetyl-1-pyrolline (2AP) biosynthesis in plants. 2AP is the volatile compound which provides fragrance in rice. Biosynthesis of $2 \mathrm{AP}$ occurs when $\mathrm{BADH} 2$ loses its function as suppressor gene. Aromatic rice cultivars naturally incur mutation of $\mathrm{BADH} 2$ gene at $8 \mathrm{bp}$. In this experiment, aromatic mutant rice lines derived from irradiation of Sintanur cultivar by gamma rays with dose of $100 \mathrm{~Gy}$ were studied in molecular level. These mutant lines were characterized at the $\mathrm{M}_{10}$ plantgeneration under the assumption that genetically these aromatic mutant rice lines were homozygotic. Several primers related to aroma in rice have been used for polymerase chain reaction (PCR) in a thermal cycler instrument. Gel electrophoreses were carried out using 1.5\% agarose in TAE buffer. DNA fragments at $254 \mathrm{bp}$ and $355 \mathrm{bp}$ (base pair) were taken and amplified by primer for nucleotide sequencing of these fragments. Molecular identification and characterization after electrophoresis showed that the mutant line from AR1020 can be differentiated from AR.1080 at $254 \mathrm{bp}$. Nucleotide sequence data from of these DNA fragments showed that point mutations (deletions and substitutions) occurred at the BADH2 gene in exon 7; those are called second mutation and were caused by gamma rays effects. The Sintanur variety was used as check cultivar and its DNA sequence was compared to that of the AR.1020 mutant line. The results from both DNA sequences (from cv. Sintanur and AR.1020) derived from fragments at $254 \mathrm{bp}$ show that point mutations occurred within exon 7 and earlier stop codon occurred in the AR.1020 mutant rice line. Further, the use of EA primer in PCR resulted in detection of deletion and substitution of nucleotides in the AR.1020 mutant line.
\end{abstract}

\section{INTRODUCTION}

Gamma rays have been widely used in mutation breeding for improving crops such as rice, soybean and banana for breeding purposes. The use of gamma rays possesses the advantage of gamma ray's ability to penetrate deeply into target cells and cause mutations in DNA genome. These mutations provided genetic variability at successive generation as sources for selection of desirable traits in a breeding program [1]. According to Morita et al. [2], gamma ray exposures of rice genome can create

\footnotetext{
* Corresponding author.

E-mail address: ishak@batan.go.id

DOI: http://dx.doi.org/10.17146/aij.2016.479
}

point mutations such as deletions or substitutions. Based on nucleotide sequences analysis, it was found that deletions of around 1-16 bp frequently occur. Gamma rays created genetic variability which is caused by mutation. Naturally, genetic diversity within species can be identified using microsatellite DNA in fragrance rice [2-10], also identification of germplasm collection of basmati rice cultivar from India, they are genetic variability among these cultivars [11-13]. According to myint et al., [14] that Myanmar's aromatic rice difference with indica or japonica type and Badh2 allele showed three base pair insertion.

Kovach et al. [15] mentioned that a close evolutionary relationship exists between the 
Basmati variety and the Japonica gene pool, but a recent report also mentions that the betaine aldehyde dehydrogenase (BADH2) gene is not the only gene responsible for fragrance in rice, and it is possible that there are other pathways for biosynthesis of 2-acetyl-1-pyrroline (2AP) [16].

A rice breeding program can be directed at improving aromatic rice performance, which is to say, providing the strongest rice aroma, by means of creating the second mutation of the $\mathrm{BADH} 2$ gene. When this gene loses its function as a suppressor, it will occur conversion from a dominant allele to a recessive one. The betaine aldehyde dehydrogenase (BADH2) gene in rice is known as a suppressor of the expression of fragrance in rice, and the recessive allele of BADH2 gene provides rice aroma [17-21]. Chen et al. [19] mentioned that $\mathrm{BADH} 2$ gene product blocked the synthesis of 2AP. One of BADH2 gene's functions is to synthesize gammaaminobutyric acid (GABA); high GABA concentrations block 2-acetyl-1-pyrroline (2AP) synthesize and vice versa $[17,19]$. $2 \mathrm{AP}$ is a volatile compound and a flavor component in rice. Fragrance in rice is caused by the accumulation of volatile compounds of $2 \mathrm{AP}$, and their expressions [18-20] because of the loss of $\mathrm{BADH} 2$ gene function. According to Braburry et al. (20) the accumulation of 2AP in aromatic rice is caused by the deletion of eight nucleotides at exon seven of the $\mathrm{BADH} 2$ gene. A perfect marker for identifying fragrance gene in rice was proposed by Bradburry et al (21). Bourgis et al. [22] characterized Asian aromatic rice varieties such as Azucena, Basmati, and Jasmine-like rice. Their results showed that identical mutations occur in Basmati and Jasminelike rice. The occurrence of more point mutations in the $\mathrm{BADH} 2$ gene can lead to the deactivation of these gene and reduction of the suppressor function for 2AP. Recent report mentioned that 2AP accumulation was not only caused by 8 bp deletion within exon 7 in the BADH2 gene, but possibly follows another biochemical pathway for the synthesis of the 2AP compound(23). Most of aromatic varieties from South and Southeast Asia do not show the 8 bp deletion such as mentioned by Bradburry et al. [20]. The mechanisms of 2AP biosynthesis in plants are not similar, but GABA acts as suppressor for 2AP biosynthesis; for instance, the activity of $y$-aminobutyraldehyde dehydrogenase (AADH) also synthesizes GABA in Bassialatifolia Roxb.

Several molecular markers can be used for identification of genes linked to fragrance in rice [12], such as SSR markers [5-15]. The DNA marker reported by Bradburry et al. [21] can clearly show the difference between aromatic rice and non- aromatic rice, but fails to differentiate the Indonesian local aromatic rice variety derived from cv. Pandanwangi (data is not shown).

\section{EXPERIMENTAL METHODS}

As much as 200 gram of rice seeds derived from Sintanur variety were irradiated by gamma rays with a dose of $100 \mathrm{~Gy}$. These irradiated seeds were sown at a rice field for $M_{1}$ plant and subsequently produced $\mathrm{M}_{2}$ seeds. $\mathrm{M}_{2}$ plants generation were grown for selection purposes such as number of tiller, number of seeds per tiller, weight of 1000 seeds, vegetative growth, harvested ages, and fragrance of leaves. Rice screened for the best fragrance phenotypic performance is continuously grown until the $\mathrm{M}_{5}$ generation. The diagram of the experiment can be seen in Fig. 1.

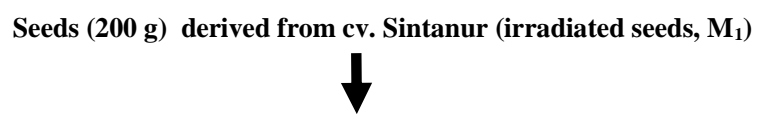

M1 Plants generation (The Plants produced $M_{2}$ seeds)

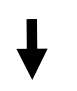

M2 Plants (selection based on phenotypic performance)

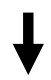

Selected M3 Plants

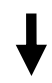

Aromatic observation of M4 generation Plants

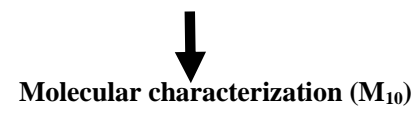

Fig. 1. Diagram of selection methods for phenotypic performance.

\section{Qualitative test for fragrance in rice}

The method used for qualitative test for fragrance in rice follows Mia et al. [24]. The leaves of each mutant line at seedling stage (one-month old plants) were cut to $4 \mathrm{~cm}$ and immersed in eppendorf tubes filled with $1 \mathrm{ml}$ of $\mathrm{KOH}(1.7 \%)$; the tubes' cap were immediately closed, and it was waited for an hour before evaluated. The fragrance of each mutant line based on scores was evaluated as strong aroma $(+++)$, medium aroma (++), mild aroma (+), or without aroma (0). Mutant lines with strong aroma 
were then selected for molecular analysis of their $\mathrm{BADH} 2$ gene.

\section{DNA isolation}

The DNA isolation method was according to Doyle and Doyle,cit. Mahdi, et al., [25] with a slight modification. Leaves of 30-day old plants were used; $500 \mathrm{mg}$ of leaves was mixed with $1 \mathrm{ml}$ CTAB buffer in a mortar and ground with a pestle until fine debris cells were obtained. These debris cells were transferred into centrifuge tubes and $3 \mathrm{ml}$ of CTAB buffer was added. The mixed solution was prewarmed at $60^{\circ} \mathrm{C}$ for one hour. Afterward, an equal volume of mixed chloroform and isoamyl alcohol (24:1) was added. The solutions were gently shaken up and down until thoroughly mixed. These solutions were then centrifuged at $4000 \mathrm{rpm}$ for 10 minutes. Supernatant samples were taken by pipet and transferred to fresh new tubes. Twice its volume in isopropanol was added into each tube, and the tubes were shaken gently and then kept in freezer $\left(-20^{\circ} \mathrm{C}\right)$ for 30 minutes. DNA samples were collected by centrifugation for 5 minutes and was then diluted in PCR-grade doublydistilled water.

\section{Polymerase chain reaction for aromatic rice}

Primers were used for $\mathrm{BADH} 2$ gene mutation detection as presented on the Table 1, as was published by Bradburry et al. [21]. PCR reactions were carried out in a $25 \mu 1$ PCR tube consisted of 2 unit taq DNA polymerase, $200 \mu \mathrm{M}$ dNTP mix, $2.5 \mathrm{mM} \mathrm{MgCl}_{2}, 200 \mathrm{nM}$ DNA template, and $0.3 \mu \mathrm{M}$ primers. PCR cycles were carried out with pre denaturation at $94^{\circ} \mathrm{C}$ for 4 minutes, and subsequently 72 cycles were performed, each of which consisted of denaturation at $94^{\circ} \mathrm{C}$ for 40 seconds, annealing at $55^{\circ} \mathrm{C}$ for 1 minute, and extension at $72^{\circ} \mathrm{C}$ for 1 minute.

\section{Agarose gel electrophoresis}

Agarose $1.5 \%$ in TAE buffer has been used as running gel. An 8- $\mu 1$ sample of DNA derived from PCR products was taken and mixed with $2 \mu 1$ loading buffer to fill it for each of slot of gel. The running time of the gel was 30 minutes. The gel was then immersed in TAE buffer containing $0.5 \mu \mathrm{g} / \mathrm{ml}$ ethidium bromide (EtBr) for 20 minutes and shaken gently at $50 \mathrm{rpm}$. DNA fragments in agarose gel were visualized under UV light and photographed.
Table 1. DNA primers used for PCR on aromatic and nonaromatic rice mutantline.

\begin{tabular}{lll}
\hline \multicolumn{1}{c}{ Primer } & \multicolumn{1}{c}{ Sources } \\
\hline ESP & $\begin{array}{l}\text { External sense } \\
\text { primer; }\end{array}$ & $\begin{array}{l}\text { Bradbury, } \text { et al., Mol. } \\
\text { Breeding, 16:279- } \\
283,2005 \text { (12) }\end{array}$ \\
5'-TTGTTTGGAGCTTGCTGATG-3' & & \\
IFAP & $\begin{array}{l}\text { Internal fgr } \\
\text { ant. Prim. }\end{array}$ \\
5'-CATAGGAGCAGCTGAAATATATACC-3' & Non-fragr. \\
INSP & & \\
5'-CTGGTAAAAAGATTATGGCTTCA-3' & & \\
EAP & & \\
5'-AGTTGCTTTACAAAGTCCCGC-3' & & \\
Baedbury's primer & External \\
& ant.primer & \\
\hline ESP & & TAG, 1177:353- \\
5'-TTGTTTGGAGCTTGCTGATG-3' & & \\
AR-3 & & \\
5'-ACCAGAGAGCAGCTGAAATAT-3' & & \\
Called EA primer & & \\
\hline
\end{tabular}

\section{Fragments DNA sequencing}

DNA fragments were taken from the agarose gel by scalpel and were then extracted using spin column (Qiagen). These DNA fragments were then sent to Macrogen Laboratory for sequencing.

\section{RESULTS AND DISCUSSION}

The mutant line of AR.1020 was derived from cv. Sintanur irradiated at a dose of $10 \mathrm{Krad}$ using gamma rays from Co-60. This aromatic mutant line reached more than 10 plant generations $\left(\mathrm{M}_{10}\right)$ and is a genetically homozygote and established mutant line. DNA molecular analysis were done for identification of the second mutation within BADH2 gene. The AR.1080 mutant line was also observed; it was derived from crossing between the mutant line of AR.10K and cv. Diahsuci. We have six aromatic mutant lines derived from irradiated cv. Sintanur; however, in this experiment, only the AR.1020 mutant line was taken for DNA fragment sequencing because it exhibited the strongest rice aroma when tested with $1.7 \% \mathrm{KOH}$. The results of the qualitative test of rice aroma with $1.7 \% \mathrm{KOH}$ can be seen in Table 2. The AR.1020 mutant line provided stronger rice aroma compared to other mutant lines and their parental line (cv. Sintanur). Jewel et al. (26) identified relationship among SSR primers with rice aroma, results showed that RM223 showed homozygous condition of $f g r$ gene. Kumari et al., (27) reported that rice aroma can be qualitatively assessed using $1.7 \% \mathrm{KOH}$ solution. This solution was able to 
release $2 \mathrm{AP}$ gas from the leaves, and it was able to differentiate between aromatic and non-aromatic rice as well. Based on these qualitative data, DNA sequences of fragment derived from $254 \mathrm{bp}$ and 355 bp were analyzed. Polymerase chain reaction (PCR) to amplify these DNA fragments used Bradbury's primer and EA primer (Table 1). Results of agarose gel electrophoresis showed that $254 \mathrm{bp}$ as an aromatic fragment and $355 \mathrm{bp}$ as a non-aromatic fragment (Fig. 2(a)). Similarly reported by Kiani [28] in a selection of F2 populations for aromatic rice used marker aid selection.

Table 2. Result of qualitative testing of rice aroma using $1.7 \% \mathrm{KOH}$

\begin{tabular}{|c|c|c|c|c|}
\hline No. & Genotypes & $\begin{array}{c}\text { Qualitative } \\
\text { test }\end{array}$ & Origin & \\
\hline 1 & AR.1020 & +++ & $\begin{array}{l}\text { Irradiated cv. } \\
\text { Sintanur }\end{array}$ & Aromatic rice \\
\hline 2 & AR1030 & ++ & $\begin{array}{l}\text { Irradiated cv. } \\
\text { Sintanur }\end{array}$ & Aromatic rice \\
\hline 3 & AR. 1040 & ++ & $\begin{array}{l}\text { Irradiated cv. } \\
\text { Sintanur }\end{array}$ & Aromatic rice \\
\hline 4 & AR.1050 & ++ & $\begin{array}{l}\text { Irradiated cv. } \\
\text { Sintanur }\end{array}$ & Aromatic rice \\
\hline 5 & AR.1060 & ++ & $\begin{array}{l}\text { Irradiated cv. } \\
\text { Sintanur }\end{array}$ & Aromatic rice \\
\hline 6 & AR.1070 & 0 & & Non-aromatic \\
\hline 7 & AR.1080 & 0 & $\begin{array}{c}\text { Crossing } \\
\text { between } \\
\text { AR.10K } \\
\text { mutant line } \\
\text { with cv. } \\
\text { DiahSuci }\end{array}$ & Non-aromatic \\
\hline 8 & cv. Sintanur & ++ & $\begin{array}{l}\text { Checked } \\
\text { variety }\end{array}$ & Aromatic rice \\
\hline 9 & cv.Ciherang & 0 & $\begin{array}{l}\text { Checked } \\
\text { variety }\end{array}$ & Non-aromatic rice \\
\hline
\end{tabular}

Notes: +++, strong aroma; ++, medium aroma; 0 , non-aroma,

The non-aromatic fragment was found within AR.1080 mutant line and Ciherang cultivar, but the aromatic fragment was not found there whereas it was found in AR.1020, Sintanur and Gilirang cultivars. The use of AR3 (forward primer) and Esp (reverse primer) in a PCR reaction of rice mutant line showed that aromatic rice and non-aromatic rice could not be clearly differentiated (Fig. 2(b)). Point mutations from all mutant genotypes can be detected after DNA fragments were sequenced (Fig. 3), and it was shown clearly that mutation occurred within the DNA fragment of AR.1020. According to Bourgis et al. [22] the mutation of Asian aromatic rice cultivars is monophylogenetic, having the same mutation as in Basmati and Jasmine like-rice varieties.

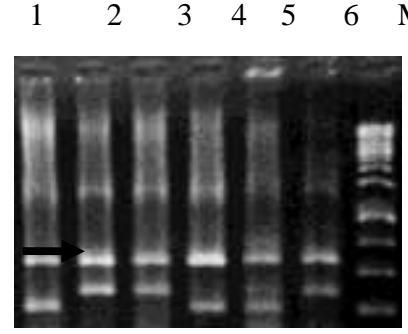

(a)

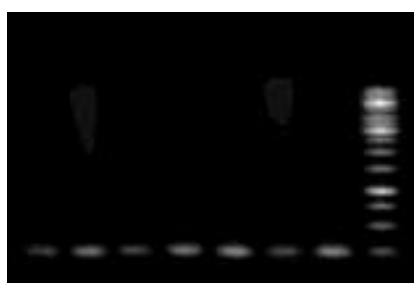

(b)
Fig. 2. (a)-(b), DNA Fragment-banding pattern,

(a), lane 1-6, AR.1020, AR.1070, AR.1080, cv. Sintanur, Gilirang, cv. Ciherang, and $\mathrm{M}$ was DNA marker. Arrow indicated aromatic fragment (254 bp),

(b), lane 1-8, AR1020, AR.1030, AR.1070, AR.1080, Sintanur, Gilirang, and Ciherang

Sintanur and Gilirang cultivars were aromatic rice, and they were used as checked variety (control). Results of DNA sequencing from these checked variety fragments and amplified by Bradburry's primer showed that there were deletion of eight bp within exon 7. This DNA sequence data was similar with reference (Fig. 4) which was reported by Bradburry et al., [20], which mention that mutation within the $\mathrm{BADH} 2$ gene caused the synthesis of $2 \mathrm{AP}$ in aromatic rice. DNA mutation occurred within exon 7, i.e deletion of $8 \mathrm{bp}$. This was regarded as the first mutation of BADH2 gene and allows synthesis of $2 \mathrm{ACP}$, because of the loss of function of the BADH2 gene as suppressor. Similarly, as reported by Arikit et al [29], transcription level of GmAMADH2 was low in aromatic soybean when compared to non-aromatic one because of frame-shift mutation, while the 2AP level is increased. Chen, et al. [19] also mentioned that BADH2-E2 and BADH2-7 mutations induced 2AP formation, whereas the precursor 2AP biosynhesis was proline [19], it was disruption of BADH2 gene in homozygous mutant through mutagenesis created rice fragrance. [30]; these mutations lead to early stop codon such as reported by Bradbury et al. [20].

DNA sequence analysis among DNA fragments of AR.1020 mutant line, Sintanur, and Ciherang cultivar were carried out by using EA and Bradbury's primers. Comparison of the DNA sequences of AR.1020 mutant line and Sintanur, derived from DNA fragment for aromatic rice, showed that within the $\mathrm{BADH} 2$ gene, alterations occured which was caused by gamma ray-induced mutation. Alterations of these nucleotides were shown as TAATGAAG (Sintanur) was converted to TATGCAC (AR.1020). Point mutations such as 
deletion, transversion, and insertion can be seen on Fig. 3. The second mutation was detected within exon 7 of BADH2 gene. The results of nucleotide sequence analysis showed the deletion of adenine and substitutions from $\mathrm{A}$ to $\mathrm{C}$ and from $\mathrm{G}$ to $\mathrm{C}$ within the DNA fragment of AR1020 aromatic rice mutant line. These short nucleotide sequences above were similar with the ones in the AR.1080 non-fragrance rice, because AR.1020 was derived from the crossing between the Diah suci cultivar and AR.10K aromatic mutant line; however, they are different from the accumulation of $\Delta$-pyrroline with methylglyoxal, leading to 2AP. The accumulation of $\Delta$-pyrroline with methylglyoxal is caused by the loss of function from BADH2 gene [17]. Beside that, 2AP biosynthesis, which has proline as a precursor, is also influenced by the regulation of proline biosynthesis which is influenced by up and down regulation gene expression related to enzymes proline for biosynthesis pathway [17]. DNA fragments with sizes of $254 \mathrm{bp}$ and $355 \mathrm{bp}$ were sequenced for identification of gene mutation within exon 7. Specific allele correlated with aroma was identified by Shams, et al., [31]. These aroma controlled by recessive gene [32]. Aromatic DNA fragment of 254 bp (Fig. 4) indicated that the aromatic rice mutant line exhibited similar mutations with references of DNA sequences from Kome ID:J023088C02, cit. Bradbury et al. [20]. Comparison of DNA sequences from Sintanur and AR.1020 showed that early stop codon took place in the mutant rice line, but not in the Sintanur cultivar. Putative short polypeptide chain indicated that Glycine $(\mathrm{G})$ converted to aspartate acid and it was continued by proline $(\mathrm{P})$ and so on (Fig. 5).

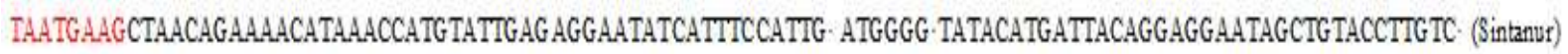

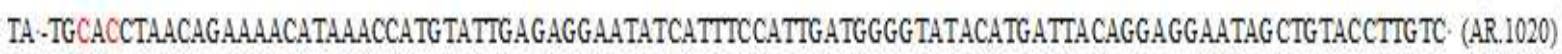 TAATGCAACCTAACAGACTAATAAACCATGTATTGAGAGG-ATATCATTTCCATTGATGGGGTATACATGATTACAGGAGGAaAgCTGTACCTTGTC- (Ciherang) IACACCAGGGTGTGATGACAAagGaGCACCGGCTTCA GAaACCTAATCCAGTCACTATGTTTAGCACACCTGAaGgAagACCAACCTCTTTA CACACATCA. (Sintanur) TACACCAGGGTGTGATGACAAAGGAGCACCGGCTTCA GAAACCTAATCCAGTCACTATGTTTAGCACACCTGAAGGAAGACCAACCTCTTTACACACATCA (AR.1020)

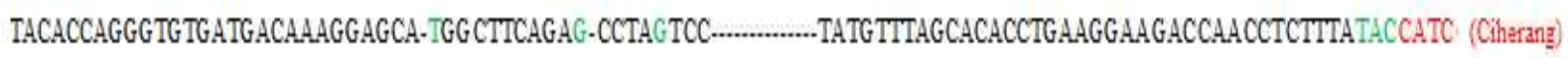

Fig. 3. Comparison of fragments of DNA sequences among rice mutant line and cv.Sintanur (aromatic rice) as parent and cv.Ciherang (non-aromatic rice)

$$
\begin{aligned}
& \text { aggttgcatttactgggagttatgaaactggtaaaaagattatggcttcagctgctcctatggttaag }\left({ }^{(*}\right) \\
& \text { aggttgcattlactgggagttatgaaactggtatata--.--_-n-ttcagctgctcctatggttaag } \quad\left(^{*}\right) \\
& \text { aggttgcatttactgggagttatgaaactggtatata-_-_-_-ttcagctgctcctatgacccct (Sintanur) }
\end{aligned}
$$

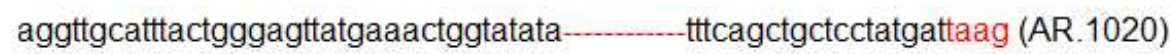

Note: taa, stop codon; $\left({ }^{\star *}\right)$, DNA sequences from non-aromatic rice as reference; $\left({ }^{\star}\right)$, references of aromatic rice

Fig. 4. DNA sequences forSintanur, AR.1020, and reference of DNA sequences from:Kome ID:J023088C02, cit. Bradbury et al., 2005)

$$
\begin{aligned}
& \text { VAFT G S Y ET GI Y F S C S Y G Stop (AR.1020) } \\
& \text { VAFT GSY ET GI Y F S C S Y D P++ (Sintanur) }
\end{aligned}
$$

Fig. 5. Short polypeptide chain within exon 7. 


\section{CONCLUSION}

The second mutation of $\mathrm{BADH} 2$ gene in mutant rice lines was detected in exon 7 when Bradbury's and EA primers were used. This mutation was induced by gamma rays. Deletion of nucleotide and substitution from purine to pyrimidine or vice versa were the most common point mutations observed.

\section{ACKNOWLEDGEMENT}

The author thanks Tisna Sanjaya and Yulidar who helped to take care of aromatic rice mutant lines since 2004. This research was partly funded by DIPA PusatAplikasi Isotop danRadiasiBATAN, 2014.

\section{REFERENCES}

1. Ishak, Indonesian Agronomic J. 40 (2012) 105.

2. R. Morita, M. Kusaba, S. Iida et al., Genes Genet. Syst. 84 (2009) 361.

3. A.M. Sayib, M.M. Hossain, A.T.M.J. Mosnaz et al., J. Bio. Sci. Biotech. 1 (2012) 107.

4. N.B. Patel, N. Dirhi, R. Shrivastava et al., Plant Archives 1 (2015) 1151.

5. K.C. Samal, N. Meti, D.N. Bastia et al., BMR Biotechnology 1 (2014) 1.

6. K. Venkatesan and K.V. Bhat, SABRAO Journal of Breeding and Genetics 47 (2015) 248.

7. N. Meti, K.G. Samal, D.N. Bastia et al., African J. Biotech. 12 (2013) 4238.

8. M. Hasan and M.S. Raihan, Turkish Journal of Agriculture-Food Science and technology 3 (2015) 107.

9. S. Roy, A. Banerjee, B. Mawkhlieng et al., PLoS ONE 10 (2015) e 0129607.

DOI:10.1371/journal.pone.0129607

10. N. Agrawal and R. Shrivastava, J. Rice Research 8 (2015) 1.

11. S.M. Shah, S.A. Naveed and M. Arif, Pak. J. Botany 45 (2013) 423.

12. R.K. Salgotra, B.B. Gupta, J.A. Bhat et al., PLoS ONE 10 (2015) e0131858.

DOI:10.1371/journal.pone.013858
13. V.P. Rai, A.K. Singh, H.K. Jaiswal et al., Turkish J. Botany 39 (2015) 209.

14. K.M. Mynt, B. Courtois, A-M. Risterucci et al.,. Rice, a Springer open Journal 5 (2012) 20.

15. M.J. Kovach, M.N. Calingacion, M.A. Fitzgerald et al., PNAS 106 (2009) 14444.

16. G. Shao, S. Tang, M. Chen et al., Genomic 101 (2013) 157.

17. A.B. Nadaf, K.V. Wakte and R.L. Zanan, Plant Science \& Research 1 (2014) 102.

18. F.S.G. Hashemi, M.Y. Raffi, M.R. Ismail et al., Plant Sci. 32 (2013) 445.

19. S. Chen, Yi. Yang, W.W. Shi et al., The Plant Cell. 20 (2008) 1850.

20. L.M.T. Bradbury, T.L. Fitzgerald, R.J. Henry et al., Plant Biotechnology Journal 3 (2005) 363.

21. L.M.T. Bradbury, R.J. Henry, Q-S. Jin et al., Molecular Breeding 16 (2005) 279.

22. F. Bourgis, R. Guyot, H. Gherbi et al., Theor. Appl. Genet. 117 (2008) 353.

23. V. Hinge, H. Patil and A. Nadaf, Appl. Biochem. Biotech. 178 (2016) 619

DOI:1007/s12010-015-1898-2

24. M.F. Mia, S.S. Begum, M.M. Islam et al., Int. J. Biol. Res. 2 (2010) 07.

25. H.J. Mahdi, R. Andayani and Ishak Aziz, Tropical Life Science Research 24 (2013) 65.

26. Z.A. Jewel, A.K. Patwary, S. Maniruzzaman et al., Agriculturist 9 (2011) 82.

27. P. Kumari, U. Ahuya, S. Jain et al., Asian J. Plant Sciences 11 (2012) 190.

28. G. Kiani, Afr. J. Biotechnol. 10 (2011) 15845.

29. A. Arikit, T. Yoshihashi, S. Wancana et al., Plant Biotechnol. J. 9 (2011) 75.

30. Q. Shan, Y. Zhang, K. Chen et al., Plant Biotechnol. J. 13 (2015) 791.

31. F.D. Shams, M.M.A. Kuddus, K.M. Nasiruddin et al., Plant Tissue Cult \& Biotechnol. 22 (2012) 65.

32. W.A. Sarhadi, N.L. Hien, M. Zanjani et al., J. Crop Sci. Biotechnol. 11 (2014) 17. 